DOI: https://doi.org/10.47405/mjssh.v6i11.1147

\begin{tabular}{|c|c|}
\hline 4 & Malaysian Journal of Social Sciences and Humanities (MJSSH) \\
\hline $\begin{array}{l}\text { Malaysian Juoural of } \\
\text { Social ccciecces and }\end{array}$ & Volume 6, Issue 11, November 2021 \\
\hline (MJ-sSH) & e-ISSN : 2504-8562 \\
\hline & $\begin{array}{l}\text { Journal home page: } \\
\text { www.msocialsciences.com }\end{array}$ \\
\hline
\end{tabular}

\title{
Exploring Victim Blaming Attitudes in Cases of Rape and Sexual Violence: The Relationship with Patriarchy
}

\author{
Haezreena Begum binti Abdul Hamid ${ }^{1}$ \\ 1Faculty of Law, University Malaya (UM), Kuala Lumpur, Malaysia \\ Correspondence: Haezreena Begum binti Abdul Hamid (haezreena@um.edu.my)
}

\begin{abstract}
This article explores the relationship between patriarchy and victim blaming in cases of rape and sexual violence. It explores how women's dependence on, and subordination to men has been used to blame victims in cases of rape and sexual assault. The article will examine how patriarchal norms that are deeply entrenched in existing laws, traditions, religion, and social practices have been used to blame women in cases of rape. It will also explore how victim blaming attitudes have and continue to be used as a tool to absolve the perpetrator from their crimes. Using discourse analysis to examine the existing literature, the article will highlight how sexual violence are sometimes minimised and trivialised in courts and media. As well as this, the study adopts a feminist lens and critiques the imbalance of power that exist between men and women. The article will highlight how patriarchal norms have been institutionalised in all layers of social structures and contest how female victims of sexual violence are sometimes ridiculed and devalued in court. Within this finding, the construction of women's sexuality and the limited criminal justice protection will be discussed in depth. The article concludes by arguing that patriarchal norms can be destructive and obstructive in achieving fairness and justice for victims of rape and sexual violence. Therefore, immediate steps must be taken to address victim-blaming attitudes by propagating more gender equality practices and instilling such practices in all levels of society and state institutions.
\end{abstract}

Keywords: patriarchy, rape, sexual violence, victim blaming, victim blaming attitudes

\section{Introduction}

Gender roles and stereotype behaviours are influenced by a variety of factors which are deeply entrenched in cultures and social practices. Throughout the centuries, men are depicted as 'naturally' dominant in both identity and status while women are depicted as subordinate to men. The general dominant stereotypes position women as weak, inferior, passive, and dependent on men while men are presumed to be naturally aggressive, strong, superior, and independent. Within these settings, men are perceived as naturally aggressive (Grosu-Rădulescu, 2016) and women are expected to guard and police themselves from being assaulted by men (Riffe, Lacy, \& Fico, 2005). Such positioning reinforces 'male supremacy' or 'male dominance' which originates from patriarchy. Patriarchy is a system where men dominate women although the form and degree of oppression has varied considerably in different cultures over time (Kandiyoti, 1988). It justifies male dominance by maintaining women's inferiority and instability (Mumtaz, Shahid, \& Levay, 2013). 
A patriarchal system can be defined as a system of men's dominance in actions and ideas (Soman, 2009). This imbalance of power has led to a situation where men as a social category, are able to oppress women individually and collectively (Ibid). Within this settings, women's choices and decisions about their bodies and lives becomes controlled and regulated by the dominant male rule (Hirschman, 2016). Men becomes the 'idealised' authority (Zayer \& Coleman, 2015) while women becomes the 'vulnerable' group (Elliot \& Elliott, 2005) which reinforces the gender dichotomy of male and female in society (West \& Zimmerman, 1991). Women are also conditioned to feel humiliated and ashamed for expressing themselves in any form or shape (Unnithan, 2017). They are expected to blame themselves when they feel ashamed (Ibid). Such attitudes influences how individuals, organisations and communities respond to rape and sexual violence (Powell, 2014). It also affects the criminal justice system and instil men's entitlement to sex and women's bodies (Ibid). Consequently, victim blaming attitudes become accepted as a normal form of defence and becomes a legitimate reason to justify sexual assaults. It puts the onus of the abuse on the victim instead of the perpetrators. Thus, this article will explore how victim blaming attitudes have and continue to be used as a tool to absolve the perpetrator from their crimes.

\section{Sexual Violence}

Sexual violence against women is regarded as a violation of human rights in which the dignity and equality of women are not recognized (World Health Organization, 2021). The World Health Organization (WHO) (2002) defines sexual violence to include 'any sexual act, comments or advances, or acts to traffic a person' by way of coercion regardless of any relationship the person may have with the victim' (p.149). Sexual violence encompass various forms of sexual assault such as rape, sexual harassment, sex trafficking, and sodomy, with rape being categorised as a war crime and a heinous form of crime against women. Other forms of sexual violence would include coerced contact between the mouth and penis, vulva, or anus (Ibid). Coercion in sexual violence may involve psychological intimidation, blackmail, threats or in situations where a person is mentally incapable of understanding the situation (Ibid).

According to WHO, rape occurs when there is a forced or coerced penetration of the vulva or anus, using a penis or other body parts or object (Ibid). Similar definition is included in the Malaysian Penal Code for the offence of rape. However, the Act only recognises women as victims of rape. This becomes problematic because men and transgenders can also become victims of rape. However, this article will not delve into gender aspect of the law but aims to focus on how rape is defined and absolved in Malaysia. According to section 375 of the Penal Code, rape is defined as having sexual intercourse with a woman against her will or without her consent, or by instilling fear of death or hurt to herself or any other person. Anyone found guilty under this provision can be imprisoned for a term up to 20 years with whipping. The Act prescribes tougher punishment for rape of a female under 16 years of age regardless of any consent that might have been given (see Section 376 of the Penal Code) with maximum imprisonment of 30 years and whipping of not less than 10 strokes. This punishment is also imposed on persons who are convicted of raping a pregnant woman or causing a woman to commit suicide due to the rape and several other circumstances (Ibid). Although sexual violence can be inflicted against both men and women and encompass various forms of sexual assault (as earlier discussed), this article will mainly focus on female rape with minimum discussion on other forms of sexual violence.

According to feminist scholars, the unequal power relations between men and women perpetuates sexual violence against women as it deeply entrenched in cultural factors and values (Kalra \& Bhugra, 2013). However, the perception towards sexual violence depends on the strength of women's roles and rights in each country and community. For example, in countries with strong feminist cultures, women's role and status are placed equally to men whereas cultures that are described as patriarchal normalises the superior status of men over women. This settings perpetuates the creation of a 'rape culture' that normalises the use of misogynistic language and objectification of women's bodies. Within this settings, rape and sexual violence becomes glamorised through the media which excuses, normalises, tolerates, and even condone sexual violence. This eventually creates a society that ignores 
and discounts women's security and well-being. As a consequence, rape and sexual violence becomes minimised and trivialised by apportioning blame to the victim while excusing the actions of the perpetrators (Gravelin, Biernat, \& Bucher, 2019). Such environment facilitates the creation and continuation of a 'rape culture' because common social beliefs and attitudes supports the idea of associating violence with sex (Anderson \& Doherty, 2008). Consequently, sexual violence becomes part of the norm and is given less consideration to its seriousness and importance (Ibid). 'Rape culture' is premised on the belief that men are sexually aggressive in nature while women are sexually passive and are meant to be dominated by men (Field, 2004). Therefore, men should not be blamed for causing sexual violence (Ibid). Such beliefs have led to victim blaming attitudes to be accepted as a normal form of defence. It has also become a legitimate reason to justify sexual assaults in the media and courts.

\section{Patriarchy and Victim Blaming}

The traditional and cultural values about women's role in society are widespread in Malaysia (O'Brien, 1983). In a country where the majority of the population are Malay Muslims, the marginalisation of women is intertwined or synonymous with the Malay cultural traditions, values and language, and Islamic precepts and teachings (Chin \& Daud, 2015). Within the gender binary and divide, man is 'naturally' dominant in both identity and status (Ibid). As Kalthom, Noor, \& Wok (2008, p. 454) points out:

Women's role is oriented more towards family matters rather than self-fulfilment implying that when faced with having to make a choice between career and family, family is always given priority. In a way, the present Malay women are caught in a dilemma between the modern challenges of life and traditions. While many are now employed, they are still expected to be responsible for the family and to maintain the traditional perception of a woman.

The portrayal of an 'ideal woman' is unfair as it places a high degree of pressure upon women to prove that they have been raped or sexually assaulted. Vicinus envisioned the 'ideal woman' as 'the 'perfect wife,' a woman who, as well as being a mother, provides all the goods and services necessary to the maintenance of the male-headed household' (Martin, 1981). The inequalities between male and female roles are further obscured by perceiving such roles as 'natural' or 'normal' (Ibid). By normalising gender roles, women internalise society's norms of the 'ideal woman' and they become part of the psyche (Joseph, 1996). As a result, women teach and police other women to conform to the attributes of an 'ideal woman' to produce a society in which male power necessitates the subordination of women.

According to Miller-Prieve (2016), societal and cultural standards placed upon women creates negative self-evaluations in women when the 'ideal' standards are not met. Women who deviate from the 'ideal' standards are considered deviant, defiant and lacks the credibility of a victim. Similarly, in cases of rape, these attributes are often used as a benchmark in determining the credibility of the complainant instead of focusing on the unlawful act itself. According to Larcombe (2002), an 'ideal' or 'real' rape victim should always be morally and sexually virtuous and must also appear to be vigilant, cautious, and unprovocative. To discredit a victim's testimony, the defence often focus on the failure of the victim to comply with the sexual and behavioural standards of the 'ideal' victim (Ibid). Although section 146A of the Evidence Act aims to protect victims from being questioned about their past sexual history and sexual activity other than the accused during cross examination, rape victims are still faced with 'humiliating' questions about their clothing and sexual history during trials, and the court remains slow to interject. They are also expected to act and react in a certain way which reflects their intention to resist the assault (Amir, 1971). This includes the proportion of strength used in resisting the perpetrator and if resistance occurred instantly (Holmstrom \& Burgess, 1991). Although the lack of resistance does not necessarily entail consent or voluntariness, there is still a tendency to apportion blame to women victims and deflect the actual scenario. This is because victim blaming allows people to believe that such events could never happen to them. 


\section{Women's Dignity}

To ensure equal and safe protection on women, Malaysia has ratified the 1979 Convention on the Elimination of All Forms of Discrimination against Women (CEDAW) in August 1995. The CEDAW aims to ensure women's equal access to, and equal opportunities in, political and public life including the right to vote, the right to education, health, and employment, the right to stand for election, and the need to equal protection of laws against rape and other forms of violence (see Article 16). Malaysia has also allowed the CEDAW provisions to be used in its domestic courts. This was visible in the case of Noorfadilla Binti Ahmad Saikin v. Chayed bin Basirun [2012] 1 CLJ 769 who sued the government for gender discrimination when she was revoked of her appointment as a relief schoolteacher upon her pregnancy (Neo, 2012). Although the CEDAW does not supersede the domestic laws and the Malaysian constitution, the convention is binding and can be used as a legitimate source to interpret laws regarding gender and sexual violence.

Besides CEDAW, Article 8 of the Malaysian Constitution also prohibits any form of discrimination on the basis of gender "except as expressly authorized by the Constitution ("Federal Constitution"). The Court of Appeal in the case of Lembaga Tatatertib Perkhidmatan Awam, Hospital Besar Pulau Pinang v Utra Badi A/L K Perumal (2000), 3CLJ 224, 39(CA) decreed that it is the fundamental right of every person within the shores of Malaysia to live with common human dignity. Gopal Sri Ram JCA in the case stated that a person who is deprived of his/her reputation is also deprived of his/her right to life according to Article 5(1) of the Federal Constitution (Ibid). As such, the right to reputation becomes a part of human dignity (Ibid). Based on such a principle, sexual offences have been condemned as the 'gravest crime against human dignity', because of the feelings of humiliation, degradation and guilt endured by the victim. Although such condemnation is meant to protect women from being sexually harmed, it has also provided a pathway for state institutions to control women's bodies and behaviour. In this instance, patriarchal norms have been institutionalised in all social structures including judicial institutions. It has also instilled victim blaming attitudes and misogynistic views in cases of rape. In this regard, women who deviate from the attributes of an 'ideal woman' are often blamed for causing their own victimisation.

\section{Methodology}

This study was conducted using discourse analysis derived from primary and secondary sources. 'Discourse' is simply the way we think, talk, and write, or generally communicate, about a given topic (Klajn, 2020). According to Hodges et. al (2008), researchers using empirical discourse use broad themes and functions of language to draw links between inter-personal tension and analyse social practices, individual and institutions. Discourses permeating a given society serve to organize and dictate our perceptions of the preferred and dominant ideologies (Cole, 2019; Gee, 1999). These discourses are considered truthful, normal, and right, while others remain side-lined, marginalised, stigmatised, or considered wrong, extreme, and even dangerous (Ibid). Thus, this article explores the various sets of discourse and analyse the themes that emerge from those discussion. According to Snape \& Spencer (2003, p. 200), discourse analysis 'examines the way knowledge is produced within different discourses and the performances, linguistic styles and rhetorical devices used in particular accounts.' It is a field of research composing of mostly qualitative approaches which is used to study the relationship between language used and the social world (Johnson \& McLean, 2020). Discourse analysis is used by many fields and has many approaches, methods, and frameworks. As in the article, the underlying factors of victim blaming is highlighted in order to challenge rhetoric ideas and statements on the 'idealised' version of an 'ideal' victim by offering a deeper perspective on the relationship between patriarchy and victim blaming.

The article uses a feminist lens and offers a distinctive approach to a research that is multidimensional. According to Harding, feminist research is produced for the purpose of action against power (Harding, 2020). In the context of this article, this would include the action against the power of patriarchal system and the interlinked structures that intersect to surveil, control and oppress women (Ibid). The research conducted on this article is generally confined to the analysis of written texts, 
including case laws, books, journal articles, legislations, published reports, newspaper and magazine articles, and websites of non-governmental organizations (NGOs), covering the period from 1970 to 2021. Statistics are also taken from the NGO websites which provides data obtained from the police and government agencies in Malaysia. As well as this, research on Brunei, India and other countries are derived from newspaper reports and official websites. The most common keywords used for this analysis are terms and phrases which include: 'rape', 'victim-blaming', 'patriarchy', 'sexual violence', and 'victim blaming attitudes', 'gender roles', and 'ideal woman'. This article demonstrate how victim-blaming attitudes have acted as an obstacle for victims of rape and sexual violence to achieve fairness and justice in court and in the eyes of the public.

\section{The Institutionalisation of Patriarchal Norms}

The concept of patriarchy is embedded in social structures and has become a defining feature of societal structures. In Southeast Asian countries such as Malaysia, Indonesia and Brunei, states often reproduce patriarchal attitudes and sustain male dominance and power in society. Accordingly, women are placed in subordinate positions, which conveys the message that their ability to make decisions cannot be trusted (McFadyen, 2000). This perpetuates women's dependency on men and sustains men's dominance and power over women. To sustain the patriarchal system, gendered identities are formed through processes of socialisation within families, schools, religious institutions, government agencies and media (Carter, 2014). These institutions, among others, instil culturally appropriate attitudes and behaviours in individuals and maintain practices of gender hierarchy by generating conformity and compliance through systemic and structural control(Ibid).

Based on a research conducted in Malaysia in 2015, it was found that primary schools overly relied on 'masculine'1 textbooks for girls' education (Islam \& Asadullah, 2018). ${ }^{2}$ Women are often depicted as individuals who are involved in domestic and indoor activities while men are portrayed as leaders and workers (Islam \& Asadullah, 2018). While this itself can be strongly disputed and condemned for dictating gender roles, an infographic requiring girls to protect their modesty or risk being shamed and ostracised by friends and family was also found in a Malaysian school text-book for nine-year-olds in 2019 (Lin, 2019). The infographic received strong condemnation from women NGOs and activists and have been removed from the textbook. Another recent example can be seen through an article which was published in the Health Ministry's website entitled 'Emotional Impact on Sexual Harassment Victims' (Zi, 2021). The article cited 'physical attractiveness', a 'charming personality', and a 'sexy body shape' as factors that 'invite' unwanted sexual attention from men and will 'indirectly' cause sexual harassment to occur (Ibid). Like the earlier example, this post that was uploaded in 2016 has also been recently deleted after strong condemnation from NGOs and women activists. Such forms of education not only perpetuate the victim-blaming culture, but also normalises rape and violence against women.

The institutionalisation of patriarchal norms are also visible in judicial institutions particularly in rape and sexual offences. Although the definition of rape in Malaysia encompass a broader scope and set of circumstances, ${ }^{3}$ cases have always coalesced around the presence of force and resistance in acts of rape. In this regards, female complainants who do not display visible signs of stress or marks of physical violence will be discredited and less likely to be believed by law enforcers and judicial system. As a consequence, those who have experienced a lower degree of physical victimisation or who are unable to present sufficient evidence that they have been raped or sexually assaulted may be blamed by the judges, juries, media, community, or the legislature for causing their own victimisation (Erez, 2013). In these situations, women are blamed because they do not conform to stereotypical constructions of a 'real' rape victim'. For example, in the case of Hj Tahamit bin Hj Jamudin v Public Prosecutor [2012] 1 MLJ 861, Steven Chong J, the Trial Judge in this case convicted the accused, a 60 -year-old retired army officer of two offences of attempting to rape a 14-year-old girl pursuant to

\footnotetext{
${ }^{1}$ Masculine textbooks in this article refers to masculine generic constructions or merely male referenced, and the association between all masculine generic nouns and pronouns.

2 This research was also conducted in Indonesia, Pakistan, and Bangladesh.

${ }^{3}$ Not just limited to consent and free-will.
} 
s376 (1) and 511 of the Penal Code. The accused was also convicted for attempting to have carnal knowledge of a girl under 16 years of age contrary to the Unlawful Carnal Knowledge Act, Chapter 29 on 7 April 2010. The accused was sentenced to nine years imprisonment on the first offence, 11 years imprisonment on the second offence, and three years on the third offence making it 14 years in total and he appealed to the Court of Appeal in Brunei Darussalam. Upon hearing submissions from his counsel and the prosecutor, the COA sustained the convictions but felt that the 14 years imprisonment was excessive. Mortimer P at p. 863 held:

The appellant caused none of the serious harm which attended most instances of the full offence. He was not responsible for the girls having to testify; there was consent, no resistance, force or trauma, no distress to mother and family and no loss of virginity. Both girls were sexually experienced and there was no loss of innocence. The appellant had served his country in the army for 19 years and was now over 60 years of age. These were weighty matters of mitigation to which effect must be given without belittling the seriousness of the offences committed (see paras 36-38).

This case indicates the seriousness of victim blaming attitudes in courts. It demonstrates how victim's sexual history and lack of 'resistance' are used to reduce blame on the appellant (accused), and hence his sentence. It also shows blatant disregard to victims dignity and privacy by referring to their chastity, purity and sexual behaviour but considers the accused past services to his country. This clearly shows how double standards and patriarchal norms operate in the judiciary system.

On the contrary, the consideration given in the case of Augustine Foong Boo Jang v Public Prosecutor [1990] 1 MLJ 225 sought to consider the various circumstances and imbalance of power held between the victim and the accused - maid and employer. In this case, the accused was charged for raping his maid and the defence counsel alleged that the maid consented to the sexual intercourse. However, the Judge in this case sought to dispel presumptions of consent by demarcating consent and submission. The learned Judge argued that while consent always imports submission, submission does not necessarily import consent. This is further illustrated in a report made to the Home Secretary in England which is set out in the judgment of R v Olugboja 3 All ER 443 at p 447:

......lack of consent is the crux of the matter and this may exist though no force is used. The test is not 'was the act against her will?' but 'was it without her consent'?

......It is, therefore, wrong to assume that the woman must show signs of injury or that she must always physically resist before there can be a conviction for rape......

Although the lack of resistance does not necessarily entail consent or voluntariness, there is still a tendency to apportion blame to women victims. Such practices which aims to invoke some guilty feeling on the part of the victim not only revives the victim's trauma of being raped but also blames and shames the victim. This can lead to 'irreparable harm' and invoke feelings of powerlessness, worthlessness, depression, self-disgust, and even suicidal on the victim (Weiss, 2010). As a result, rape victims may be reluctant to report their cases to the police for fear of going through vigorous investigation and intense questioning. Many who have lodged reports have also been said to have withdrawn their complaints because of family pressure or for fear of being subjected to the stigma and scrutiny of a rape investigation (Ariff, 2021). This clearly demonstrate the barriers women face in seeking justice. These obstacles acts to silence them from speaking up while perpetuating a culture of impunity on perpetrators of rape.

\section{The Construction of Women's Sexuality}

The tendency to consider women as subordinate to men has led to the justification of traditional violent practices and gender-based violence which is disguised as 'protection.' For example, the practice of female genital circumcision (FGC) is considered harmful and violent by WHO and the international community (World Bank, 2018) but is a common practice amongst Muslims in Malaysia. Common reason given is to protect women from becoming 'wild' and to manage 'lustful' desires (Admin-S, 2018). Although such reasons have never been attested or corroborated by scientific 
evidence or the holy Quran, this ritual continue to be performed on mostly new-born female babies (Ibid). Any person who disputes this practice will be side-line, ostracised and labelled as an 'unbeliever'. There are also no laws concerning FGC in Malaysia and the Malaysian Medical Council is silent on this subject (Rashid \& Iguchi, 2019).

Apart from FGC, religion has always been used to as a tool to subjugate women and blame women for sexual offences in Malaysia. Some sermons openly connect or insinuate women who do not cover their 'aurah' and wear 'tudung' (hijab) with sexual violence. In one sermon entitled "Aurat: Antara Kebebasan dan Maruah Diri" (Aurat: Between freedom and self-dignity) which was delivered on Feb 6,205 , women were asked to cover their 'aurah' to avoid the evil gaze of men and to avoid negative incidents such as rape, illicit sex, and incest from happening (Eng, 2015). Such types or sermons are not only incorrect but also disrespectful, irresponsible, and biased. It also does not make sense as there's been women who have been raped even though they were covering their 'aurah'. For example, Noor Suzaily Mukhtar a 24-year-old computer engineer was raped, sodomised, and murdered in a bus in 2000 despite doning a 'tudung' (hijab) and long skirt during the incident. Her attire did not prevent the rape from happening nor protected her from being raped. Therefore, it is pertinent to understand that rape involves more than just covering your 'aurah' but the intention to harm, subjugate, and humiliate victims physically, mentally, and verbally (Darke, 1990). Therefore, the 'cover up your aurah' message does not assist victims of sexual violence but instead shifts the blame from the perpetrators to the victims.

The blaming attitudes does not only come from the religious sectors but also individuals from all walks of life and educational background. According to Moor, attitudes and characters possessed by women have been polemicised by men to place rape offences on women (Moor, 2010). For example, in July 2020, Norazizi Samsudain, an MRSM Baling lecturer, disputed the study findings of an infographic (pie chart) on his instagram account on the causes on rape which Women's Centre of Change (WCC) had earlier issued (Malay Mail, July 7, 2020). According to WCC's findings, the police statistics have indicated that around 80 per cent of rape victims are females below 18 years of age and nearly 65 per cent of rape victims are reported to be children (including babies and toddlers) (Ibid). Out of this percentage, almost 80 per cent of incest victims were below 15 years of age, and over 90 per cent of child rapes are committed by trusted family members or friends (Ibid). Norazizi however claimed that only two out of ten cases are 'real' rape cases while majority of cases involve consensual sexual encounters. He also blamed the victims for displaying 'improper' clothing and behaviour (Ibid). Norazizi's statement suffered massive online backlash and his video was deleted after receiving 25,000 signatures petition to remove the posting (Ibid).

According to the UN Special Rapporteur on violence against women, stereotypes contribute to the violation of human rights and fundamental freedoms for women (United Nations Human Rights, 2014). The World Bank found that 35 percent of women worldwide have experienced either physical and/or sexual intimate partner violence or non-partner sexual violence, and seven percent of women have been sexually assaulted by someone other than a partner (World Bank, 2018). The level of violence committed by a partner is even more alarming as 38 percent of murders of women are committed by an intimate partner (Ibid). Although these figures show the severity of violence against women, many of the crimes committed against women originate from misogynist mindsets which originate from patriarchal practices and are regularly legitimised through culture, religion, and state institutions. Similarly, victim blaming strategies have also been institutionalised, and normalised in social institutions including courts (Walklate, 2013). This is because cultural practices and religious beliefs have been used to subjugate women and ensure that women remain subservient to men and can be controlled by the state. Therefore, states tend to offer only limited criminal justice towards female victims to ensure that women conform to the moral codes of the 'ideal woman'.

\section{Limited Criminal Justice Protection Towards Female Victims}

The public and policy makers tend to expect the victim to be sexually blameless (Doezema, 2000). Women engage in 'risky' behaviours such as casual sex, consuming drugs or alcohol, or hitchhiking 
are often considered to be partially responsible for their own victimisation (Grubb \& Turner, 2012). The consequence of such an approach is to place culpability for any victimisation onto victims themselves (Newburn, 2013). Blaming the victim allows the victimisers to convince themselves that the victim is guilty of some injustice (Fattah, 1991). It also shifts the blame from the perpetrators to victims (Ibid). This allows the offender to transform the victim into a person deserving of suffering and justifies the conscience of potential victimisers (Ibid). This is particularly evident in cases of rape where rape myths are widely believed and used in the criminal justice system. According to Burt (1983), rape myths are false beliefs about rape, rape victims and perpetrators. Rape myths allow the perpetrator to justify rape to minimise personal vulnerability (Burt, 1983).

The normalisation of rape myth has led to the institutionalisation of victim blaming attitudes in social institutions, including courts. For example, defence lawyers often seek to discredit victim's statements so that they can be blamed for the incident that has occurred (as earlier discussed). This is conducted through vigorous questioning in court to establish any provocation or culpability on the part of the victim and also by making insinuations about the victim's morality (Boyer, Allison, \& Creagh, 2018). By examining victim's behaviour and morality, the perpetrator would be able to shift the prevention of responsibility from the offender to the victim (Stringer, 2013). In this instance, an individual may find it difficult to ascribe to the title of a victim if found to be partly responsible or complicit in certain acts (Ibid). In such cases, the judiciary may refuse to recognise that the victim has been raped or deserves the title of a victim (Matthews, 2015).

For sex workers who are often regarded as criminals, sexually deviant, socially inept, and/or mentally deficient, their complaints about rape are frequently trivialised or minimised. In some cases, such complaints will be not be regarded as rape, but 'theft of services' (Williams, 2015). This is because there is a presumption that a sex worker who has consented to sexual acts for money does not have the right to forfeit her consent (Ibid). Therefore, those who complain of being raped or attacked face difficulties in convincing the authorities and are likely to be disbelieved by them because of the stigma that is attached to sex workers (Goffman, 1963). They are also perceived as 'undeserving victims' and will typically be treated as someone who contributed to their own mishaps (M.Pollak \& E.Kubrin, 2007). In this instance, the legal system perpetuates discrimination and denies access to legal protection or recourse.

Further, Amir suggested that crimes such as rape would not have happened if not without the victim's aid or cooperation, and that there is usually some form of reciprocal action between the offender and the victim (Amir, 1971; Stringer, 2013). This victim precipitation theory is founded on the myth that victims can prevent attacks by not engaging in risky behaviours (Ibid). This stems from the deeply rooted patriarchal attitudes towards sex and women's morality. For example, in a case involving an American postgraduate student of Indian origin in Delhi who was raped in 2015, the Delhi Lower Court convicted Mahmood Farouqi (the accused), a Bollywood filmmaker, and sentenced him to seven years imprisonment (Pasricha, 2017). However, on appeal, the Delhi High Court Judge set aside the conviction and ruled that 'a 'feeble no' could indicate willingness on the part of the victim' (Ibid). Although the woman had told the court that the accused forced himself on her and ignored her 'no', she stopped resisting after some point, fearing that she may be harmed (Ibid). The Delhi High Court Judge ruled 'in an act of passion, actuated by libido, there could be myriad circumstances, which can surround a consent, and it may not necessarily always mean yes in case of yes or no in case of no'(Ibid).

The women's rights activists denounced the Judge's statement, stating that it reinforced stereotypes that a rape was usually the woman's fault and the onus of preventing assault lies on her (Ibid). It also coincides with Smart's claim who argue that complainant's testimony are often doubted and discredited particularly if the incident is portrayed as a 'pornographic vignette' (Smart, 1990). As in this case, the complainant (victim) is depicted as a precipitating agent through her weak response that indicate acceptance. Therefore, she should be responsible for her own rape and is disqualified from holding the victim status (Larcombe, 2002). Thus, scholars such as Stringer (2013) and Walklate (2013) argue that the concept of victim precipitation places unreasonable requirements on victims to 
demonstrate that they are 'real' and 'deserving victims' and revamps the way responsibility and blame are accorded.

Overall, the notion of 'blaming the victim' for their own victimisation is problematic because its shifts the focus of the crime committed by the perpetrator to the victim (Walklate, 2013). An example is a rape case involving a first-year law student who was gang raped by three final-year law students inside the private university campus in Sonepat district of Haryana, India (Pasricha, 2017). According to the victim, one of the accused abducted her from the local market on Wednesday afternoon in an SUV (Ibid). She was then raped by all three accused in the vehicle until Thursday before she was dumped near the gate of her varsity (Ibid). The victim also revealed that one of the accused blackmailed her by saying that 'if she revealed the incident to anyone, then pics will be uploaded on social media' (Ibid). The trial court convicted all the accused and sentenced them to seven years imprisonment in March 2017. However, on appeal, the judges in the Punjab and Haryana High Court agreed to suspend the sentencing term and ruled:

The victim had a promiscuous attitude and a voyeuristic mind, and that her narrative does not throw up gut wrenching violence that normally precede or accompany such incidents. The testimony of the victim suggests that there was an alternate story of casual relationship with her friends, acquaintances, adventurism, and experimentation in sexual encounters.

The rulings of the Judges in the above cases suggests that the judiciary is inclined to preclude a person from claiming or being accorded the victim status should there be any evidence or suggestion of 'immoral' behaviour, or if the victim does not display an attitude which fits the imagery of an 'ideal' woman: chaste, responsible, and cautious. As Smart noted '[t]he process of the rape trial can be described as a specific mode of sexualisation of a woman's body' with the precise and intended effect of disqualifying her testimony and experience of sexual assault' (Smart, 2013).

Larcombe (2002) points out that 'the legal discovery of rape becomes a test of the complainant's [victim] character and credit, particularly in terms of her sexual morality but also in relation to her moral integrity and trustworthiness as a witness.' Similarly, in this case, the victim's characteristics and personal lifestyle were sensationalised to shame and blame her. This shows how victim-blaming strategies are used in judicial systems. By using such strategies, women are constantly kept under control, while men are given the benefit of the doubt even in extreme cases such as the one above. This sustains men's dominance over women and ensures women remain inferior. Similar situations occur to victims of sex trafficking in Malaysia. According to Anne Keyworth, a social activist who has continuously advocated for stricter enforcement of law in the east Malaysian state of Sabah, 'some [victims] get fed up and withdraw their complaint while those who persevere feel as if they were treated as the accused and not as victims' (LaCroix International, 2016). Thus, the justice system in Malaysia has been criticised for being gender biased and unaccommodating to victims of sex trafficking and sexual violence.

Zedner (2002) argues that the victim plays a significant role in the criminal justice process, without the co-operation of the victim in reporting crime, furnishing evidence, identifying the offender and acting as a witness in court, most crime would remain unknown and unpunished. However, state institutions, including criminal justice agencies, often disregard victims' interests and/or uses victims to achieve professional outcomes, such as to win or lose the case in court. Some scholars suggest that these institutions promote a selective justice system, which only acknowledges women who fit the description of a 'legitimate' or 'real' victim (Estrich, 1987). According to Walklate (2013), such selectivity is meant to uphold patriarchal beliefs about women (as illustrated in the two examples above). This is obvious in cases relating to sexual violence where patriarchal norms are applied to determine the victim's credibility. Although there may be laws that restrict evidence of a witnesses 'bad character' or sexual history, such as in the Malaysian Evidence Act 1950, this does not prevent the defence from introducing evidence, or asking questions that can be extremely distressing to witnesses. This shows that legislation on its own does not necessarily translate into justice for victims. 


\section{Conclusion}

The prevalence and impact of sexual violence in women's lives is still not publicly acknowledged despite the enactment of laws to protect women from rape and sexual harm. The patriarchal norms discussed in this article has become the basis of women's identity and victimhood. These norms have been instilled through various structures and are reinforced through generations. As such, women are constantly battling with patriarchal ideas and beliefs in order to justify their identity and rights, even their own victimhood. The law has invariably colluded to oppress women, and this has been done through principles that advantage men and disadvantage women. Making the victim the sole recipient of blame in cases of rape can not only cause severe psychological damage for the victim and risk prolonging the after-effects of the assault, but it also defeats the purpose of having rape and sexual violence laws.

\section{Acknowledgements}

The writer wish to express her gratitude to the reviewers for their constructive comments and feedback.

\section{References}

Abdullah, K., Noor, N. M., \& Wok, S. (2008). The Perception Of Women's Roles And Progress: A Study Of Malay Women. Social Indicators Research, 89(3), 439-455.

Amir, M. (1971). Patterns in Forcible Rape. Chicago: University of Chicago Press.

Ariff, I. (2021). 120 Rape Cases Seen, but Only Three Went to Trial. FMT (Kuala Lumpur), May 2, 2021. https://www.freemalaysiatoday.com/category/nation/2021/05/02/120-rape-cases-seen-butonly-three-went-to-trial/.

Boyer, T., Sue Allison, \& Helen, C. (2018). Improving the Justice Response to Victims of Sexual Violence: Victims' Experiences. Wellington, New Zealand: Gravitas.

Burt, M. (1983). A conceptual framework for victimological research. Victimology, 8(1), 261-269.

Carter, M. J. (2014). Gender Socialization and Identity Theory. Social Sciences, 3(2), 242-63. https://doi.org/10.3390/socsci3020242.

Christie, N. (1986). The Ideal Victim. In From Crime Policy to Victim Policy: Reorienting the Justice System, edited by Ezzat A. Fattah, 17-30. London, UK: Palgrave Macmillan, 1986.

Cole, N. L. (2019). Introduction to Discourse in Sociology: A Sociological Definition.

Doezema, J. (2000). Loose Women or Lost Women? The Re-Emergence of the Myth of 'White Slavery' in Contemporary Discourses of Trafficking in Women.. Gender Issues, 18(1), 23-50.

Elliot, R., \& Elliott, C. (2005). Idealized images of the male body in advertising: A reader-response exploration. Journal of Marketing Communications, 11(1), 3-19.

Eng, Chong. (2015). Sermon Shouldn't Keep Blaming Attire for Rape. Malaysiakini (Kuala Lumpur), February 9, 2015.

Estrich, S. (1987). Real Rape: How the System Victimizes Women Who Say No. Cambridge, Massachusetts: Harvard University Press, 1987.

Evidence Act, 1950 (Act 56), Laws of Malaysia

Fattah, E. A. (1991). The Victims and Their Victimizers. Chap 6 In Understanding Criminal Victimization, edited by Ezzat A. Fattah, 131-54. Toronto, Canada: Prentice-Hall Canada Inc, 1991.

Goffman, E. (1963). Stigma: Notes on the Management of Spoiled Identity. New York: Simon \& Schuster, Inc., 1963.

Grubb, Amy Rose, \& Emily Turner. (2012). Attribution of Blame in Rape Cases: A Review of the Impact of Rape Myth Acceptance, Gender Role Conformity and Substance Use on Victim Blaming. Aggression and Violent Behavior, 15(5)443-52.

Hodges, B. D., Kuper, A., \& Reeves, S. (2008). Qualitative Research: Discourse Analysis. BMJ: British Medical Journal, 337(1), 570-572. 
Holmstrom, Lynda Lytle, \& Ann Wolbert Burgess. (1991). The Victim of Rape: Institutional Reactions. New Brunswick: Transaction Publishers, 1991.

Islam, Kazi Md. Mukitul, \& M. Niaz Asadullah. (2018). Gender Stereotypes and Education: A Comparative Content Analysis of Malaysian, Indonesian, Pakistani and Bangladeshi School Textbooks. PLoS ONE, 13, 1-24.

Ismail, Siti Zubaidah. (2011). Constructing Some Possibilities for Compensation as Part of Legal Remedies for Rape Survivors: The Case of Malaysia. European Journal of Social Sciences, 26(2), 176-84.

Darke, J. L. (1990). Sexual Aggression." In Handbook of Sexual Assault. Applied Clinical Psychology., edited by Marshall W.L., Laws D.R. and Barbaree H.E. Boston, MA: Springer, 1990.

Joseph, S. (1996). Patriarchy and Development in the Arab World. Gender and Development, 4(2).

Kandiyoti, D. (1988). Bargaining with Patriarchy. Gender and society, 2(1), 274-90.

LaCroix International. (2016). Malaysia Is Failing Victims of Human Trafficking. LaCroix International (Paris, France), August 22, 2016. https://international.la-croix.com/news/malaysiais-failing-victims-of-human-trafficking/3733\#.

LaFree, G. D. (1981). Official Reactions to Social Problems: Police Decisions in Sexual Assault Cases. Social Problems, 28(1), 582-94.

Larcombe, W. (2002). The 'Ideal' Victim V Succesful Rape Complainants: Not What You Might Expect. Feminist Legal Studies, 10(2), 131 - 48.

Lin, Mayuri Mei. (2019). Malaysia Revises 'Victim-Shaming' School Text Book. BBC News (London, England), January 16, 2019.

M.Pollak, Jessica, \& Charis E.Kubrin. (2007). Crime in the News: How Crimes, Offenders and Victims Are Portrayed in the Media. Criminalk Justice and Popular Culture, 14(1), 60-83.

Martin, D. (1981). Battered Women - Scope of the Problem. In Perspectives on Crime Victims, edited by B. Galaway and J. Hudson, 190-201. Toronto: C.V Mosby Company, 1981.

Matthews, Roger. (2015). Female Prostitution and Victimization: A Realist Analysis. International Review of Victimology, 21(1), 85-100.

McFadyen, Alistair. (2000). Bound to Sin: Abuse, Holocaust, and the Christian Doctrine of Sin. Cambridge: Cambridge University Press, 2000.

Miller-Prieve. (2016). Women, Shame, and Mental Health: A Systematic Review of Approaches in Psychotherapy. Vienna: St. Catherine University.

Moor, A. (2010). She Dresses to Attract, He Perceives Seduction: A Gender Gap in Attribution of Intent to Women's Revealing Style of Dress and Its Relation to Blaming the Victims of Sexual Violence. Journal of International Women's Studies, 11(4), 115-27.

Mumtaz, Zubia, Umber Shahid, and Adrienne Levay. (2013). Understanding The impact of Gendered Roles on the Experiences of Infertility Amongst Men and Women in Punjab. Reproductive Health, 10(3), 1 - 9.

Neo, Jaclyn L. (2012). Incorporating Human Rights: Mitigated Dualism and Interpretation in Malaysian Courts. Asian Yearbook of International Law, 18(1), 1-37.

Newburn, T. (2013). Victims, Victimisation and Victimology. In Criminology, edited by T. Newburn, 351-78. London: Routledge, 2013. Reprint, 2nd.

P., R. G., \& Unnithan, A. B. (2017). Self and Identity of Being an Ideal Woman: An Exploratory Qualitative Study. IIM Kozhikode Society \& Management Review, 7(1), 33-44.

Pasricha, Anjana. (2017). Rights Groups Furious About Indian Court Decision on Consent in Rape Cases. Voice of America (Washington, D.C), September 29, 2017. https://www.voanews.com/a/indian-court-rules-feeble-no-could-be-concent-in-rape-casesparking-furor/4049623.html.

Penal Code (Act No. 574) Laws of Malaysia.

Rashid, A., \& Iguchi, Y. (2019). Female genital cutting in Malaysia: a mixed-methods study. BMJ Open, 9(4), e025078. doi:10.1136/bmjopen-2018-025078

Smart, C. (1990). Law's Truth/Women's Experience. In Dissenting Opinions: Feminist Explorations in Law and Society, edited by R. Graycar, 1-20. Sydney: Allen and Unwin, 1990.

Smart, Carol. (2013). Women, Crime and Criminology. First ed. London: Routledge, 2013.

Stringer, Rebecca. (2013). Vulnerability after Wounding: Feminism, Rape Law, and the Different. SubStance, 42(3), 148 - 68. 
The World Bank (2018). Gender-Based Violence (Violence against Women and Girls."accessed 2/04/2019, 2019, http://www.worldbank.org/en/topic/socialdevelopment/brief/violence-againstwomen-and-girls.

United Nations (2014). Gender Stereotypes and Stereotyping and Women's Rights., accessed May 13, 2019 , https://www.ohchr.org/documents/issues/women/wrgs/onepagers/gender_stereotyping.pdf.

Vicinus, Martha (1972). Suffer and Be Still: Women in the Victorian Age. Indiana: Indiana University Press, 1972.

Malay Mail (2020). Victim Blaming Perpetuates Silence, Injustice - Wcc. Malay Mail (Kuala Lumpur), July 7, 2020. https://www.malaymail.com/news/what-you-think/2020/07/07/victimblaming-perpetuates-silence-injustice-wcc/1882170.

Walklate, Sandra (2013). ed. Victimology: The Victim and the Criminal Justice Process. Oxon, UK: Routledge, 2013.

Weiss, Karen G (2010). Too Ashamed to Report: Deconstructing the Shame of Sexual Victimization. Feminist Criminology, 5(3), 286-310.

Zedner, Lucia (2002). "Victims." Chap. 13 In The Oxford Handbook of Criminology, edited by Mike Maguire, Rod Morgan and Robert Reiner, 419-56. Oxford: Oxford University Press, 2002.

Zi, Tan Mei (2021). Health Ministry Slammed Online for Victim-Blaming Sexual Harassment Article, Other Questionable Posts Still Up." Malay Mail (Kuala Lumpur), April 13, 2021. https://www.malaymail.com/news/life/2021/04/13/health-ministry-slammed-online-for-victimblaming-sexual-harassment-article/1966168.

Singapore Development Studies Centre Monograph No. 32. (pp. 193-216). Canberra, Australia: The Australian National University.

Admin-S. (2018, November 13). Female Circumcision: Culture And Religion In Malaysia See Millions Of Girls Undergo Cut. Retrieved from https://www.malaysiatoday.net/2018/11/13/female-circumcision-culture-and-religion-in-malaysia-see-millions-ofgirls-undergo-cut/ 